\title{
The Immune System and Responses to Cancer: Coordinated
}

\section{Evolution [version 1; peer review: 2 approved with}

\section{reservations]}

\section{Brendon J. Coventry1', Martin Ashdown², Maciej Henneberg (iD), Paul C W Davies ${ }^{4}$}

\author{
${ }^{1}$ Discipline of Surgery, Royal Adelaide Hospital, University of Adelaide, Adelaide, South Autralia, 5000, Australia \\ ${ }^{2}$ CSO Biotempus Ltd, Melbourne, 3003, Australia \\ ${ }^{3}$ Biological Anthropology and Comparative Anatomy Unit, School of Medical Sciences, University of Adelaide, Adelaide, South \\ Australia, 5005, Australia \\ 4Beyond Center for Fundamental Concepts in Science, Center for the Convergence of Physical Science and Cancer Biology, Arizona \\ State University, Tempe, AZ, 85287, USA
}

V1 First published: 12 Aug 2015, 4:552

https://doi.org/10.12688/f1000research.6718.1

Second version: 06 Nov 2020, 4:552

https://doi.org/10.12688/f1000research.6718.2

Latest published: 27 Jan 2021, 4:552

https://doi.org/10.12688/f1000research.6718.3

\section{Abstract}

This review explores the evolutionary interaction and co-development between immune system and somatic evolution. Over immense durations, continuous interactions between microbes, aberrant somatic cells, including malignant cells, and the immune system have successively shaped the evolutionary development of the immune system, somatic cells and microorganisms through continuous adaptive symbiotic processes of progressive immunological and somatic change providing what we observe today. The immune system is powerful enough to remove cancer and induce long-term cures. Our knowledge of how this occurs is just emerging. It is less clear why the immune system would detect cancer cells, when it is usually focused on combatting infection. Here we show the connections between immunity, infection and cancer, by searching back in time hundreds of millions of years and more to when multicellular organisms first began, and the immune system eventually evolved into the truly brilliant and efficient protective mechanism, the importance of which we are just beginning to now understand. What we do know is that comprehending these points will likely lead to more effective cancer therapies.

\section{Keywords}

Immune system, evolution, cancer, mutation, immune response, immunosurveillance, immunotherapy

\section{Open Peer Review

Approval Status

version 3

(revision)

27 Jan 2021

version 2

(revision)

06 Nov 2020

version 1

12 Aug 2015

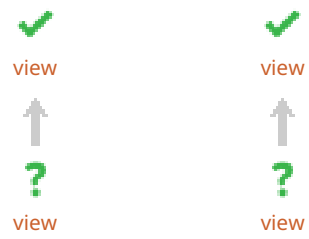

1. Jonathan M. Austyn, University of Oxford, Oxford, UK

\section{Angus Dalgleish, St George's University of London, London, UK}

Any reports and responses or comments on the article can be found at the end of the article. 
Corresponding author: Brendon J. Coventry (brendon.coventry@adelaide.edu.au)

Competing interests: The authors declare that they have no financial or non-financial competing interests, nor any conflicts of interests.

Grant information: This work was supported in part by NIH grant U54 CA143682.

Copyright: @ 2015 Coventry BJ et al. This is an open access article distributed under the terms of the Creative Commons Attribution License, which permits unrestricted use, distribution, and reproduction in any medium, provided the original work is properly cited.

How to cite this article: Coventry BJ, Ashdown M, Henneberg M and Davies PCW. The Immune System and Responses to Cancer:

Coordinated Evolution [version 1; peer review: 2 approved with reservations] F1000Research 2015, 4:552

https://doi.org/10.12688/f1000research.6718.1

First published: 12 Aug 2015, 4:552 https://doi.org/10.12688/f1000research.6718.1 


\section{Introduction and overview}

It often goes unappreciated that the adaptive immune system developed hundreds of millions of years ago, and has evolved into a truly efficient protective mechanism, the importance of which we are just beginning to now understand in science and medicine. Acute immune responses have developed alongside infection and genetic diversity, as part of the entire evolutionary process of matching organism against organism. There has been a continuous development of the immune system's capacity to protect an organism against infections through rapid genetic somatic hypermutations that also lead to a dynamic, intricate interplay between genetic endowment and somatic mutations. The immune system acts as an ultimate high fidelity 'read-out' for cellular genetic change, detecting cellular aberration at very early stages as it develops, to remove or destroy aberrant cells. Such aberration arises from infection of cells by viruses, bacteria or other microbes, DNA damage, failed repair mechanisms, mutagens, and carcinogens including UV light, toxins and chemicals, and cellular ageing. Constant dynamic interaction occurs between cells and the immune system to preserve homeostasis. Because the rate of mutation during cell division and tissue turnover far exceeds the rate of malignant tumour diagnosis, the immune system must play an efficient role in detecting and eliminating aberrant and frankly malignant cells at a developmentally early stage. The reason why cancer occurs at all in humans and animals thus remains a mystery. However, the answer likely resides with observations that in the chronic state of antigen persistence the immune system continually appears to close itself down to avoid over-activation and to conserve energy. In the acute state, with exposure to each new pathogen the immune system responds rapidly over several days and then typically retains 'memory' of that encounter, enabling more rapid responses upon subsequent exposure. If the antigen can be acutely removed from the system, the immune system returns to steady basal state via homeostatic mechanisms. However, if the antigen persists and cannot be removed from the organism, the immune system responds again with a further cycle of activity. Over-reactivity is limited by eliciting an inhibitory response after each activation response, in the form of negative feedback for biological homeostatic damping. This cyclic feedback phenomenon is seen right across many, if not all, biological systems in nature. In the chronic state, the immune system repeatedly activates in response to persistent antigenic signals. When the antigenic signal cannot be removed with a second 'round' of activation, another cycle of activation and then inhibition occurs. This repetitive cycle continues until the antigenic focus is eventually removed, or the organism dies. Although this is an efficient system in the acute setting, in the chronic setting where the problem persists indefinitely and does not appear to resolve, "chronic inflammation' can arise which is often far less energy efficient. Vast amounts of energy can be consumed in chronic severe inflammatory conditions. In areas of the world where infection has been effectively reduced by sanitation and other public health measures, chronic inflammatory diseases have emerged as the major causes of morbidity and mortality. Clinically, this manifests as a relapsing and remitting process, often with malaise and weight loss characteristic of many chronic illnesses. This rather maladaptive process consumes massive amounts of energy, damaging surrounding tissues and cells. Over a number of generations, natural selection can lead to efficiency improvements of immune responses to specific chronic infections through co-adaptation of hosts and pathogens; examples are endemic treponematoses ${ }^{1,2}$ or tuberculosis ${ }^{3,4}$.

This article considers cancer immunology in terms of immune system evolution and chronic inflammation.

\section{Review}

Developmental importance, genome diversity and evolutionary change

The immune system functions diversely across many organs to protect and maintain health. Importantly, the host's immune system can regulate the genomic integrity across species and generations. Protection extends to all body barrier interfaces between the external and internal environment, where invasion of microbial agents is prevented or dealt with. The protection also acts against deleterious somatic mutations of host cells. The immune system is vital for maintenance of the health of all other body systems.

Essentially, the process of DNA-based evolution, besides adapting organisms to their physical environments, has pitted organism against organism in the quest for ultimate survival. According to Darwinian principles, the surviving organisms are the most successful either in conquering and terminating competing organisms, or in reaching symbiotic balance with them. That process requires protection of host DNA and also facilitates relatively rapid genomic constitutional adaptation by acquiring and modifying useful DNA from the environment ${ }^{5}$. Indeed, the organism's DNA is added to, modified and diversified to keep ahead of the 'genetic superiority game' by mutation, plasmid transfer, viral transduction, mitotic translocations, and meiotic acquisition. The immune system undergoes constant modification of innate and adaptive immunity with exposure to antigenic stimuli both at the individual and the population levels.

The mammalian immune system represents one of the final central arbiters over the course of human Darwinian evolution. Many of the advances necessary for human adaptation have been moderated, directed and shaped by the influence of the immune system. Most fundamentally, the defense against infection and therefore survival of individuals to permit reproduction and species continuity, is underpinned by immune system function. Less obvious, though equally fundamental, is the role of the immune system in maintenance of the organism's homeostasis through removal of cells whose somatic mutations made them deleterious. Natural selection applies not only to the successful reproduction of entire organisms, but also to the clonal reproduction of cell lineages, both cancer and immunological, within an organism ${ }^{6}$.

The genes for the hypervariable regions of the antibody molecule and the genes for the hypervariable regions of the T-cell receptor, mutate at a much faster rate (hypermutation) than somatic genes under usual environmental pressure. Somatic mutation is a relatively slow process where genetic changes through selection pressure on survival and evolution usually require generations of cell divisions. The immune system genes, however, constantly rapidly mutate in order to generate diverse conformations capable of binding the multitude of antigens to which an individual is exposed. Many of those antigens might be associated with threat and danger, 
for example, from microbial invasion. The immune system design has necessarily evolved, through continuous successive approximation, to detect subtle molecular cell surface aberrations. This occurs through both non-specific, and specific B- and T-cell, mechanisms in an elegantly integrated manner.

\section{How the genome monitors itself and evolves}

Somatic changes of organisms occur generally at a gradual pace as part of the slow, but effective, evolutionary process through such mechanisms as random mutation, natural selection and viral infection. For example human morphological characteristics, such as stature, brain size and tooth size change at rates ranging from 0.3 darwins to 65 darwins ${ }^{7}$. Microbial DNA sequences, for example from retroviruses like HIV, Herpes viruses and Mycobacterium tuberculosis, have been identified in the human genome, and these genes must have been structurally incorporated over time from repeated exposure, interaction and exchange between mammalian and microbial DNA ${ }^{8,9}$. Human Endogenous Retroviruses (HERVs) are estimated to make up $8 \%$ of the human genome, though fragmented and replication incompetent, it bears testament to long and intimate genetic interactions between a parasite with a few genes and 10,000 nucleotides, and a host of some 22,000 genes and some 2.85 billion nucleotides ${ }^{10,11}$. Interestingly, the (uninfected) $\mathrm{C} 57$ black mouse has several whole genomic copies of the LMP56 retrovirus in its germline ${ }^{12}$. Clearly, the retrovirus became inserted into the murine genetic complement in the mammal's evolutionary past $^{13-15}$. When infected with the virus in the experimental situation, the mouse develops a chronic immunodeficiency disease, the clinical course of which parallels HIV/AIDS in humans ${ }^{16}$. It is now suggested that this chronic disease state is due to the murine immune system failing to differentiate between self and non-self, such that it homeostatically attenuates or down-regulates the response against the virus in vivo ${ }^{17,18}$. Failure to resolve the disease is due to persisting viral (self) antigens. The experimental similarity to the immune response in murine cancer models is strikingly compelling. In the case of cancer in the mouse the persisting antigens are due to the growing cancer which appears to exert a similar attenuating effect $^{19}$.

Over the millennia the constant exchange of genetic material between host and environmental microorganisms has offered incremental adaptive advantage to both organisms, but in fundamentally different ways, perhaps comprising the ultimate symbiotic relationship, since both have evolved and survived ${ }^{20}$. However, many organisms can expand rapidly, possess mechanisms for evasion of host defences, and can mutate at a rate that far outpaces somatic evolutionary change via much faster division/reproduction rates. This may explain the immune system's evolved ability to match these rapid microbial mutational rates to more effectively neutralize them via innate mechanisms, antibody production and cellular responses. Examples are the microorganisms that rapidly expand and produce outbreaks of disease in humans, animals, plants and insects, sometimes with transmission across species. Rapid, immediate 'revolutionary' adaptive change is advantageous to keep the immune system ahead of microbial mutation, virulence and growth $^{21}$. To oppose mutated, infected and otherwise aberrant cells, the immune system has a number of adaptive and protective mechanisms. These include somatic hypermutation genes for generation of hypervariable region binding domains for antibody molecules by plasma (B-) cells, and for hypervariable T-cell surface receptors by T-cells for rapid response to antigen exposure. In this way, adaptive immune responses can rapidly generate multiple molecules with variable affinity for binding whole or fragmented antigens. An analogy would be 'random number generation' to break unknown digital codes, or in contemporary terms to 'hack into' a computer system across encrypted firewalls ${ }^{22-24}$.

Without adequate host organism defence, infection would cause cellular damage and death. Humans are estimated to harbour some $10^{14}$ microbes, mostly bacteria, while we consist of only $10^{13}$ mammalian cells ${ }^{25-27}$. It might therefore be argued that in a cellular sense we are more bacterial than mammalian in constitution. Let's however, adhere to the notion that the host is the mammalian component. The human body, like any other multicellular organism, should be treated as a complex ecosystem whose balance is dynamically maintained by feedback interactions amongst its parts.

To understand the human immune system, we must appreciate that each facet of the immune system has evolved concurrently as life itself has evolved. The mammalian genome, therefore constantly monitors itself through the actions of the immune system, both nonspecific and adaptive. This is in order to achieve a state of evolving homeostasis to achieve progressive protection of the genome, and of cellular and tissue function, as the environmental, microbial and other pressures continually change.

\section{History of immune system development and cellular aberration}

Life on earth commenced between 3 and $4 \mathrm{Ga}$ (giga/billion years ago) as unicellular organisms adapted to survive environmental hazards through rapid reproduction and repopulation. Some $1.2 \mathrm{Ga}$ algal mats developed as the first multicellular organisms, and then about $1 \mathrm{Ga}$ more complex chlorophyll-containing organisms evolved. About $450 \mathrm{Ma}$ (mega/million years ago) even more complex plants developed and acquired fundamental innate static immune systems largely through intracellular anti-microbial molecules to resist infection principally from fungi, bacteria and viruses.

Adaptive immunity developed rather precipitously around $450 \mathrm{Ma}$ in primitive fish and amphibians, and with reptiles, about $300 \mathrm{Ma}$, this evolved rapidly for protection against infection.

Mammalian life began about $120 \mathrm{Ma}$, with immune system evolution to meet the need for local and systemic protection from invasive microorganisms, and placentation ${ }^{20}$. Indeed, for effective adaptive symbiosis the mammalian immune system must have developed evolutionary tolerance for specific microorganisms since some organisms conferred adaptive advantages and others did not.

Over a mere 60 years or so, we have investigated the intricate interplay between non-specific (innate) and more specific (adaptive) immune mechanisms for fundamental evolutionary and developmental advantage. Often viewed as separate arms of the immune response, it is clear that they are rarely mutually exclusive or separate. The division arose for experimental explanatory research reasons, rather than physiological ones, but are inextricably inseparable. 
Genomic intrinsic mutational pressures and exogenous infection of cells are significant forces capable of exerting phenotypic change to produce cell membrane 'aberration'. During cellular transformation to dysplasia, metaplasia and malignancy, cell membrane changes are detectable. Since gene mutations occur about 1 in every $10^{6}$ cell divisions, the risk of cellular aberration is high in rapidly dividing tissues, with some leading to malignant transformation. The immune system is the only system capable of high level detection and action, and must therefore detect aberrant cells early and remove them exceedingly effectively and efficiently, otherwise, the rates of cancers would exceed that observed clinically. About $10^{6}$ cells form a $5 \mathrm{~mm}$ diameter tumour from some 30 divisions (assuming a regular process applies).

\section{Fundamental reactivity to aberrant antigens}

Aberrations, arising from multiple events such as infection of cells, cellular injury, trauma, ageing or from genetic mutation, are reflected by cell surface expression of aberrant proteins, lipids (especially glycolipids) and carbohydrates. Detection of aberration through both non-specific and specific adaptive mechanisms is essential for destruction and removal of abnormal cells to restore tissue integrity. Membrane profile alterations from normal to dysplastic and malignant transformation are evident using magnetic resonance spectroscopy $^{28-30}$. The immune system is carefully tuned to detect relatively subtle changes in proteins through the standard HLA systems via Class I and II molecules, and the far less explored CD1 system for the detection of lipid, glycolipid and carbohydrate molecules ${ }^{31}$. In addition, the Fc receptor mechanism of the non-specific arm of the immune system detects foreign and altered cells. Activation of granulocytes, macrophages, B-cells and T-cells pushes the immune system in one direction or in the other, producing either overall responsiveness/activation, or inhibition/tolerance. Increasingly, it is being appreciated that all levels of the immune system can either respond or inhibit. Therefore, infected, damaged or malignant cells can be either actively eliminated or tolerated. Clinically, this is precisely what is observed, in a variety of infections and malignancies. Indeed, chronic inflammatory states have emerged as the predominant illnesses affecting many individuals, including persistent infections, autoimmunity and malignancy. Diseases such as cancer, cardiovascular disease and diabetes are now appreciated as chronic persistent inflammatory states, capable of modulation by factors such as anti-inflammatory medication and immune modulation.

\section{The cancer cell as an evolutionary entity}

Cancer cells are often portrayed as profoundly defective 'rogue' cells. Certain acquired key mutations permit loss of cellular control in division and adhesion, to evade immune destruction. The extent of genetic heterogeneity occurring within the cancer mass(es), both primary and metastatic, appears considerable ${ }^{32-36}$.

Clearly, the cancer cell appears as an adaptive and highly evolved entity able to switch on certain genes to survive the onslaught of radiation and chemotherapy, despite having genetic/chromosomal errors. So, in this sense it is a very sophisticated survival machine. So much so, that a cancer cell is often described as being "immortalized". For example, the HeLa cell line, from Henrietta Lacks who died of cervical cancer in 1951 has been cultivated for decades in tissue culture worldwide, with some 20 tonnes grown to date $\mathrm{e}^{37,38}$.
Cancer remains a major protracted health problem globally despite decades of apparent sophisticated research and monies spent, with relatively minor reductions in mortality from advanced cancers of most types ${ }^{39}$. Indeed, perhaps the strategies and "paradigms" currently used for cancer research and therapeutic intervention might be incorrect. In 2010, the successes of cancer research efforts were again questioned ${ }^{40,41}$, while in 2008 the USA National Cancer Institute, in frank admission of glacial progress, sought insights from the physical sciences into cancer biology (via 12 new so-called Physical Science-Oncology Centers; PS-OCs), hoping for radically new thinking ${ }^{42}$. Novel ideas emerged from the PS-OC programme like the atavistic theory, where cancer is viewed not so much as a "dream run" of genetic accidents conferring extraordinary capabilities, but as a "default state" in reaction to an insult or stress, where cells abandon many recently-evolved capabilities to run on ancient core functionality - a sort of basic "safe mode" for cells. In other words, cancer is an inbuilt response to damage (or poor tissue environments) rather than a product of $i^{43,44}$. Thus rather than cancer being a modern biological phenomenon, it has very deep evolutionary roots - confirmed by the fact that cancer is found across most classes of multicellular life, including simple organisms like hydra that possess only two cell types ${ }^{45}$.

Cancer represents a reversion to a more primitive eukaryotic cellular state. In the single-celled world, cells are effectively immortal, and their prime imperative is replication in the face of diverse challenges. Proliferation is thus the default state of unicellular life and it has had 4 billion years to evolve mechanisms to preserve it when threatened. A major transition in biology occurred between about 1.0 and 1.5 billion years ago with the evolution of multicellularity, and later with primitive metazoan multicellularity somewhere in the Cambrian period approximately $550 \mathrm{Ma}$. In many multicellular organisms somatic cells outsource their immortality to specialized germ cells, and accept apoptosis as the price. However, this ancient contract is vulnerable to 'cheating' (as with all cooperative biological systems) and so it must be policed by layer upon layer of regulatory control. When the control mechanisms are damaged or compromised, reversion to unconstrained proliferation may ensue, manifesting as a neoplasm. Cancer is thus an ever-present threat - an accident waiting to happen - because of "pre-programmed" deeplyentrenched, highly-protected and ancient genome parts which can be variously triggered, including by random damage. Like a genie in a bottle, the bottle can be shattered in many ways, but once the genie escapes it executes its agenda with ruthless efficiency and determinism. Thus cancer follows a broadly predictable pattern of behaviour across organ types and species, with primary tumours followed by EMT, motility, dissemination via the vasculature, colonization of remote organs, MET and secondary growth, suggesting it is a very basic biological phenomenon and not an aberration.

The atavistic theory makes some specific and testable predictions about cancer progression. In defaulting to an ancestral phenotype, cancer is more comfortable in, and may even engineer niches to recreate, conditions resembling the Proterozoic oceans in which multicellularity evolved. For example, the Proterozoic environment at that time was hypoxic (the second great oxygenation event did not take place until about 800 million years ago). Sure enough, cancer metabolism prefers the ancestral, but less energy efficient mechanism 
of anaerobic fermentation (glycolysis) over the more recentlyevolved oxidative phosphorylation. This atavistic reversion to an ancient mode of metabolism is known as the Warburg Effect and has been widely recognized, even if unexplained, since the $1930 \mathrm{~s}^{46}$. Another example concerns the long-recognized resemblance between embryo development and tumours, common features being hypoxia, cell motility (EMT), angiogenesis, invasiveness and rapid proliferation. But ontogeny roughly mimics phylogenetic evolution (von Bauer's laws of ontogeny), so a reversion to a more primitive evolutionary state closely resembles a reversion to an embryonic developmental state. It is widely known that developmental genes tend to be inappropriately up-regulated in cancer $^{47}$, and these are in turn the ancient genes controlling the basic body plan.

In a refinement for the broad-brush (and fairly uncontentious) reversion theory, Lineweaver, Davies and Vincent ${ }^{44}$ are examining the evolutionary ages of the genes that are up-regulated in cancer. This emerging field is known as phylostratigraphy. The atavism theory predicts that genes which are up-regulated in cancer (oncogenes) should be systematically older than those that are down-regulated (tumour suppressor genes), and that this skewed distribution should become more pronounced as a function of cancer progression in individual organisms. The theory thus makes a new prediction: that in cancer, there should be a correlation between gene ages and (anomalous) gene activity.

If this general trend towards a more primitive state is correct, it exposes an Achilles Heel of cancer. Reversion involves changes in cell functionality. The atavism theory claims that the gain of function in cancer is really regain of pre-existing ancient functionality. In contrast to the standard somatic mutation theory of cancer, in which neoplasms are treated as if created anew in each organism (and acquire their astonishing similarity via high-speed convergent evolution within the organism in a matter of months or years), the atavism theory asserts that cancer never invents anything new but merely appropriates, or co-opts, or re-acquires, existing biological functionalities that are deeply pre-programmed into the cells' genetic and epigenetic pathways. Conversely, loss of function in cancer occurs when cells revert to a more primitive phenotype, because in so doing they jettison, or lose, or decouple from more-recently evolved (and usually more sophisticated) capabilities. Among the (relatively) more recently-evolved biological capabilities is the adaptive immune system. The atavism theory predicts that, as cancer advances, the neoplasm progressively loses contact with adaptive immunity and becomes, in effect, immunosuppressed. In the atavism theory, cancer immunosuppression - which is well known represents a loss of function (due to a reversion to a phenotype that predates the evolution of adaptive immunity about 400 million years ago) rather than a gain of function conferring a survival trait (i.e. ability to evade immune attack). But immunosuppression is a two-edged sword. It may confer protection from immune attack, but it is also an obvious weakness, making the tumour environment vulnerable to infectious agents.

The history of the interaction of bacteria, viruses and cancer is a very long and somewhat confused one, since William Coley obtained some amazing clinical results over a century ago ${ }^{48}$. Some infections will boost the immune system and bring additional pressure on cancer cells, but some agents will directly infect the cancer cells preferentially in their immunosuppressed niches, for example oncolytic viruses. A variety of new approaches ${ }^{49-55}$ to immunotherapy exploits these features. The atavism theory predicts that advanced cancer will be particularly vulnerable to certain infectious agents, and specific treatment regimes have been advocated to take advantage of that aspect ${ }^{44,56}$.

\section{Homeostatic regulation of immune reactivity and cancer}

The relapsing and remitting behaviour of many chronic inflammatory states, such as arthritis, inflammatory bowel diseases, multiple sclerosis, and thyroiditis is well recognised. Diabetes, cardiovascular diseases and cancers of all types are now being considered similarly. The fluctuating, oscillating nature of these diseases has largely confounded our understanding to date and remained frustratingly unexplained, but is indicative that the immune system must be transitioning between stimulation/activation and suppression/tolerance phases repeatedly to produce the observed clinical picture. Moreover, oscillatory behaviour is highly characteristic of any homeostatic biological system under negative feedback control. This cyclical dynamic is a physical expression of physiological control to maintain relative constancy of the milieu intérieur, as recognised by Claude Bernard around 1867, and later Walter Cannon. Physiological constancy, or homeostatic control, of the body's immune status requires proportioned synchrony between effector stimulation $\underline{\text { and }}$ regulatory functions to be operational. Many cyclical examples, such as the diurnal temperature cycles, peri-monthly menstrual cycles, and 24-hour cortisol cycles have been elucidated by close serial monitoring.

The association between cancer and the host immune response has been recognised for over a century ${ }^{57-62}$. In animals, North et al. and more recently Klatzmann et al., demonstrated that the time of delivery of cytotoxic agents after tumour transplantation was crucial in determining whether tumour regression occurred or not ${ }^{63-72}$. Early clinical observations of inflammation and cancer regression were made by those treating cancer ${ }^{57-60}$, particularly the development of infection/fever after surgery. Chronic inflammation has been associated with cancer development, for example chronic ulceration and Marjolin's squamous cell cancer of the skin.

The immune system has innate and adaptive arms. C-Reactive Protein (CRP) is a non-specific functional analogue of immunoglobulin that binds to self/non-self cellular breakdown products of inflammation to initiate the adaptive immune responses ${ }^{73,74}$. T \& B cells respond to cellular changes due to infection, damage or mutagenesis. To fine tune and limit these responses, the ensuing immune response is down-regulated paradoxically by the same cytokines and receptors that initiated it, but on functionally different cell types. Regulatory T-cells play a major role in this homeostatic attenuation and experimental and clinical evidence has shown that when these cells are either removed or blocked, cancer can completely regress, while autoimmune conditions may develop or worsen.

In recent years, it has become clear that the immune system recognises and processes both self- and non-self antigens to either respond or tolerate the antigen, but that homeostatic balance usually prevails. 
Immune responses can therefore be thought of as a "bi-stable" system existing in either of two principal states (responsive or tolerant). Antigen is the prime mover for either of these two states, and cytokines, most notably interleukin-2 (IL2), provide the feedback loop in the time domain to govern the direction. If antigen is continuously supplied to such a system (due to tumor cell growth/turnover) logic and physiology dictate that this response must oscillate ${ }^{73-82}$. Bi-stable oscillatory systems are characteristic of any homeostatic system with a feedback loop (Figure 1).

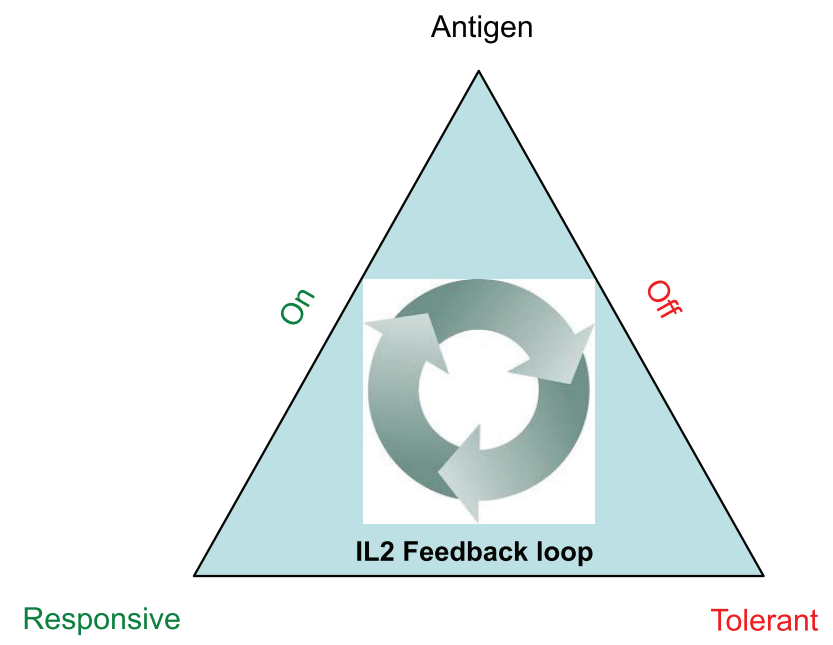

Figure 1. The bi-stable oscillatory immune system pyramid with antigen at the apex and operational feedback facilitatory and inhibitory loops, driving both responsiveness and tolerance alternately to create homeostasis.

\section{Anti-cancer agents and immune responses}

Cytotoxic agents inhibit cell division to therapeutically damage and kill tumor cells. However, cancer cells divide asynchronously. About $20-30 \%$ of malignant cells within many solid cancers are dividing at any one time-point (greater rates of division occur in some cancers such as childhood leukaemia and testicular carcinoma). Regimens have evolved often with weekly dosing of sequential 'lines' (1st, 2nd, 3rd etc) of treatments or in combinations. Repetitive dosing of agents inducing multiple cycles of cell damage and antigen release (vaccination events) from the tumour is emerging as highly significant ${ }^{56,75-77}$.

Cells of the immune system rapidly divide, but they divide synchronously and alternately (effector then regulatory) at different times sequentially to initiate then terminate an immune response in the time domain ${ }^{73-82}$.

Cytotoxic agents, unless applied discriminately, can aimlessly ablate different groups of proliferating immunological cells, as well as any proliferating tumor cells.
It is now clear that the immune system is not ignorant to the presence of tumors and that the normal homeostatic regulatory mechanisms are at the seat of the problem. This explains why immuno-modulatory agents, such as IL2, CTLA4, PD1/L1 monoclonal antibodies can deliver random dramatic complete responses in a limited percentage of late-stage cancer patients by interfering with the preexisting homeostatic suppression/tolerance ${ }^{81-88}$. All of these agents can induce tolerance. The lack of efficacy of these agents in most patients is explained by induction of tolerance with some doses via regulatory T-cells while activating with other doses, the net balance of which can determine overall clinical outcome. Interestingly, autoimmunity can result from 'overdrive' of the immune system by some immunostimulatory agents and this has often been associated with better clinical responses against the cancer.

\section{Improving results of natural selection}

Most aberrant cells appearing in the human body as a result of somatic mutations are detected and disposed of by the immune system. Some are not and can produce pathology, with the majority of clinical cases of cancer occurring in older patients. This is explicable by the fact that natural selection operates principally by differential reproduction, consequently it is unable to operate for biological characteristic selection in non-reproductive (older) individuals. Thus, over the generations immune responses to malignant cells appearing in young people became adjusted by natural selection and, statistically speaking, operate efficiently, while such responses in older age were not "reachable" by natural selection for adjustment. This principle is not only applicable to specific immune responses, but encompasses the entire regulation of homeostatic balance of an organism. In practical terms, clinical intervention should imitate adaptation by selection of immunological processes occurring in younger organisms, to support, adjust and enhance natural operation of immune systems of older patients.

\section{Concluding remarks and implications}

Although knowledge has developed deeply concerning the immune system and cancer immunology, our contemporary understanding needs to be placed in evolutionary perspective. Our immune systems are the adaptive result of the necessity for defence against persistent selective pressures from environmental microbial pathogens. Over the millennia, the immune system and other body cells have undergone a continuous adaptive symbiotic process of synchronous, coordinated, cooperative, progressive immunological and somatic evolutionary change to provide what we observe today. Gradual evolution of adaptive immunity against infected and aberrant cells now explains many of the observations regarding cancer immunity and clinical responses. It is gradually being appreciated that normal immune regulatory mechanisms are holding back a primed immune response from selectively killing cancer cells. With an appreciation that immuno-modulation of pre-existing endogenous immune responses appears to occur with most cancer therapies, there is the serious prospect that serial immune monitoring might define optimal time-points for targeted administration of therapies to engineer effective complete clinical responses in a much more predictable, reliable and durable manner in the future. If achievable, increased long-term survival from advanced cancer, with reduced toxicity, might become a reality by harnessing the immuno-modulatory 
capacity of many currently existing therapeutic agents. The cost savings would be truly enormous ${ }^{89}$.

\section{Authors' information}

The authorship represents a unique collaboration between diverse disciplines with contributors having backgrounds and qualifications in cancer surgery, immunology, immunotherapy (BJC), basic science (MLA), evolutionary biology, anatomy, anthropology (MH), and the physical sciences, cancer biology (PD). As such, this work aims to approach the problem of cancer development and immune system recognition/responses uniquely from a scientific evolutionary perspective to explain many of the clinical observations that have been already made to date. Emanating from this understanding, new approaches and therapies might then be fruitfully generated for science and clinical medicine.

\section{List of abbreviations}

IL2 interleukin-2

CTLA4 cytotoxic T-lymphocyte associated protein 4

PD-1 programmed cell death protein 1

PD-L1 programmed death-ligand 1

HLA human leukocyte antigen

CD1 cluster of differentiation 1

DNA deoxyribonucleic acid
EMT epithelial-mesenchymal transition

MET mesenchymal-epithelial transition

PS-OC Physical Science-Oncology Centers

HIV human immunodeficiency virus

AIDS acquired immunodeficiency syndrome

HREV human endogenous retroviruses

Ma mega/million years

$\mathrm{Ga}$ giga/billion years

\section{Author contributions}

BJC devised and wrote the main text; MLA contributed to the discussion on HIV/retroviruses and hyper-variable T-cell receptors; MH contributed to evolutionary discussions; PCWD contributed to cancer cell evolution. All authors prepared, read and approved the manuscript to reach the final content.

\section{Competing interests}

The authors declare that they have no financial or non-financial competing interests, nor any conflicts of interests.

Grant information

This work was supported in part by NIH grant U54 CA143682.
1. Hackett CJ: On the Origin of the Human Treponematoses (Pinta, Yaws, Endemic Syphilis and Venereal Syphilis). Bull World Health Organ. 1963; 29: 7-41. PubMed Abstract | Free Full Text

2. Hackett CJ: An introduction to diagnostic criteria of syphilis, treponarid and yaws (treponematoses) in dry bones, and some implications. Virchows Arch $A$ Pathol Anat Histol. 1975; 368(3): 229-41. PubMed Abstract | Publisher Full Text

3. Holloway KL, Henneberg RJ, de Barros Lopes M, et al.: Evolution of human tuberculosis: a systematic review and meta-analysis of paleopathological evidence. Homo. 2011; 62(6): 402-58. PubMed Abstract | Publisher Full Text

4. Holloway KL, Staub K, Rühli $F$, et al.: Lessons from history of socioeconomic improvements: a new approach to treating multi-drug-resistant tuberculosis. J Biosoc Sci. 2014; 46(5): 600-20.

PubMed Abstract | Publisher Full Text

5. Alizon S, de Roode JC, Michalakis Y: Multiple infections and the evolution of virulence. Ecol Lett. 2013; 16(4): 556-67. PubMed Abstract | Publisher Full Text

6. Greaves M, Maley CC: Clonal evolution in cancer. Nature. 2012; 481(7381): $306-13$.

PubMed Abstract | Publisher Full Text | Free Full Text

7. Henneberg M: The rate of human morphological microevolution and taxonomic diversity of hominids. Studies in Historical Anthropology. 2006; 4.2004: 49-59. Reference Source

8. Rasmussen HB: Interactions between Exogenous and Endogenous Retroviruses. J Biomed Sci. 1997; 4(1): 1-8. PubMed Abstract | Publisher Full Text

9. Krone B, Kölmel KF, Henz BM, et al.: Protection against melanoma by vaccination with Bacille Calmette-Guerin (BCG) and/or vaccinia: an epidemiology-based hypothesis on the nature of a melanoma risk factor and its immunological control. Eur J Cancer. 2005; 41(1): 104-117. PubMed Abstract | Publisher Full Text

10. Hohn O, Hanke K, Bannert N: HERV-K(HML-2), the Best Preserved Family of HERVs: Endogenization, Expression, and Implications in Health and Disease. Front Oncol. 2013; 3: 246

PubMed Abstract | Publisher Full Text | Free Full Text
11. International Human Genome Sequencing Consortium: Finishing the euchromatic sequence of the human genome. Nature. 2004; 431(7011): 931-45. PubMed Abstract | Publisher Full Text

12. Jones RB, Garrison KE, Mujib S, et al:: HERV-K-specific T cells eliminate diverse HIV-1/2 and SIV primary isolates. J Clin Invest. 2012; 122(12): 4473-89. PubMed Abstract | Publisher Full Text | Free Full Text

13. Chattopadhyay SK, Lander MR, Rands $\mathrm{E}$, et al: Structure of endogenous murine leukemia virus DNA in mouse genomes. Proc Natl Acad Sci U S A. 1980; 77(10): 5774-8.

PubMed Abstract | Publisher Full Text | Free Full Text

14. Kubo $Y$, Nakagawa $Y$, Kakimi $K$, et al:: Molecular cloning and characterization of a murine AIDS virus-related endogenous transcript expressed in C57BL/6 mice. J Gen Virol. 1994; 75(pt 4): 881-8. PubMed Abstract | Publisher Full Text

15. Kubo Y, Kakimi K, Higo K, et al.: Possible origin of murine AIDS (MAIDS) virus: conversion of an endogenous retroviral p12gag sequence to a MAIDSinducing sequence by frameshift mutations. J Virol. 1996; 70(9): 6405-9. PubMed Abstract | Free Full Text

16. Jolicoeur P: Murine acquired immunodeficiency syndrome (MAIDS): an animal model to study the AIDS pathogenesis. FASEB J. 1991; 5(10): 2398-405. PublMed Abstract

17. Beilharz MW, Sammels LM, Paun A, et al:: Timed ablation of regulatory CD4+ cells can prevent murine AIDS progression. J Immunol. 2004; 172(8): 4917-25. PubMed Abstract | Publisher Full Text

18. Meng L, Tompkins M, Miller M, et al.: Lentivirus-activated T regulatory cells suppress $\mathrm{T}$ helper cell interleukin-2 production by inhibiting nuclear factor of activated T cells 2 binding to the interleukin-2 promoter. AIDS Res Hum Retroviruses. 2014; 30(1): 58-66. PubMed Abstract | Publisher Full Text | Free Full Text

19. Ondondo B, Jones E, Godkin A, et al.: Home sweet home: the tumor microenvironment as a haven for regulatory T cells. Front Immunol. 2013; 4: 197. PubMed Abstract | Publisher Full Text | Free Full Text

20. Lee A, Nolan A, Watson J, et al.: Identification of an ancient endogenous retrovirus, predating the divergence of the placental mammals. Philos Trans $R$ Soc Lond B Biol Sci. 2013; 368(1626): 20120503. PubMed Abstract | Publisher Full Text | Free Full Text 
21. Wright $\mathrm{BE}$, Schmidt $\mathrm{KH}$, Minnick MF: Kinetic models reveal the in vivo mechanisms of mutagenesis in microbes and man. Mutat Res. 2013; 752(2): 129-37.

PubMed Abstract | Publisher Full Text | Free Full Text

22. French DL, Laskov R, Scharff MD: The role of somatic hypermutation in the generation of antibody diversity. Science. 1989; 244(4909): 1152-1157. PubMed Abstract | Publisher Full Text

23. Tomlinson IM, Walter G, Jones PT, et al:: The imprint of somatic hypermutation on the repertoire of human germline V genes. J Mol Biol. 1996; 256(5): 813-17. PubMed Abstract | Publisher Full Text

24. Jones JM, Gellert M: The taming of a transposon: $\mathrm{V}(\mathrm{D}) \mathrm{J}$ recombination and the immune system. Immunol Rev. 2004; 200: 233-48.

PubMed Abstract | Publisher Full Text

25. Bianconi E, Piovesan A, Facchin F, et al:: An estimation of the number of cells in the human body. Ann Hum Biol. 2013; 40(6): 463-71.

PubMed Abstract | Publisher Full Text

26. Savage DC: Microbial ecology of the gastrointestinal tract. Annu Rev Microbiol. 1977; 31: 107-133.

PubMed Abstract | Publisher Full Text

27. Gerritsen J, Smidt H, Rijkers GT, et al:: Intestinal microbiota in human health and disease: the impact of probiotics. Genes Nutr. 2011; 6(3): 209-240. PubMed Abstract | Publisher Full Text | Free Full Text

28. Mountford CE, Grossman G, Reid G, et al.: Characterization of transformed cells and tumors by proton nuclear magnetic resonance spectroscopy. Cancer Res. 1982; 42(6): 2270-6. PubMed Abstract

29. Mackinnon WB, Huschtscha L, Dent K, et al: Correlation of cellula differentiation in human colorectal carcinoma and adenoma cell lines with metabolite profiles determined by ${ }^{1} \mathrm{H}$ magnetic resonance spectroscopy. Int $\mathrm{J}$ Cancer. 1994; 59(2): 248-61.

PubMed Abstract | Publisher Full Text

30. Yakoub D, Keun HC, Goldin R, et al.: Metabolic profiling detects field effects in nondysplastic tissue from esophageal cancer patients. Cancer Res. 2010 70(22): 9129-36.

PubMed Abstract | Publisher Full Text

31. Coventry B, Heinzel S: CD1a in human cancers: a new role for an old molecule. Trends Immunol. 2004; 25(5): 242-248.

PubMed Abstract | Publisher Full Text

32. Burrell RA, McGranahan N, Bartek J, et al.: The causes and consequences of genetic heterogeneity in cancer evolution. Nature. 2013; 501(7467): 338-45. PubMed Abstract | Publisher Full Text

33. Munoz J, Swanton C, Kurzrock R: Molecular profiling and the reclassification of cancer: divide and conquer. Am Soc Clin Oncol Educ Book. 2013: 127-34. PubMed Abstract | Publisher Full Text

34. Murugaesu N, Chew SK, Swanton C: Adapting clinical paradigms to the challenges of cancer clonal evolution. Am J Pathol. 2013; 182(6): 1962-71. PubMed Abstract | Publisher Full Text

35. Jamal-Hanjani M, Thanopoulou E, Peggs KS, et al:: Tumour heterogeneity and immune-modulation. Curr Opin Pharmacol. 2013; 13(4): 497-503. PubMed Abstract | Publisher Full Text | Free Full Text

36. S Datta R, Gutteridge A, Swanton C, et al:: Modelling the evolution of genetic instability during tumour progression. Evol Appl. 2013; 6(1): 20-33. PubMed Abstract | Publisher Full Text | Free Full Text

37. Ncayiyana DJ: The extraordinary story of the life after death of Henrietta Lacks. S Afr Med J. 2011; 101(3): 141

PubMed Abstract

38. Njoku DB: The immortal life of Henrietta Lacks. Anesth Analg. 2013; 117(1): 286 PubMed Abstract | Publisher Full Text

39. Kiberstis PA, Travis J: Celebrating a glass half-full. Science. 2006; 312(5777): 1157. Publisher Full Text

40. Tuma RS: Large trials, small gains: is change on the way? J Natl Cancer Inst. 2010; 102(16): 1216-1217, 1223

Publisher Full Text

41. US National Institues of Health. President's Cancer Panel. 2007- 2008 annual report. 2012.

Reference Source

42. Davies P: Rethinking cancer. Physics World. 2010; 23(6): 28 Reference Source

43. Davies PC, Lineweaver $\mathrm{CH}$ : Cancer tumors as Metazoa 1.0: tapping genes of ancient ancestors. Phys Biol. 2011; 8(1): 015001 PubMed Abstract | Publisher Full Text | Free Full Text

44. Lineweaver $\mathrm{CH}$, Davies PC, Vincent MD: Targeting cancer's weaknesses (not its strengths): Therapeutic strategies suggested by the atavistic model. Bioessays. 2014; 36(9): 827-35.

PubMed Abstract | Publisher Full Text | Free Full Text

45. Domazet-Lošo T, Klimovich A, Anokhin B, et al:: Naturally occurring tumours in the basal metazoan Hydra. Nat Commun. 2014; 5: 4222.

PubMed Abstract | Publisher Full Text

46. Warburg O: On the origin of cancer cells. Science. 1956; 123(3191): 309-314. PubMed Abstract | Publisher FullText
47. Adamson ED: Oncogenes in development. Development. 1987; 99(4): 449-71 PubMed Abstract

48. Coley WB: The treatment of malignant tumors by repeated inoculations of erysipelas: with a report of ten original cases. Am J Med Sci. 1893; 105(5): 487-511.

Reference Source

49. Kim SH, Castro F, Paterson Y, et al.: High efficacy of a Listeria-based vaccine against metastatic breast cancer reveals a dual mode of action. Cancer Res. 2009; 69(14): 5860-6.

PubMed Abstract | Publisher Full Text | Free Full Text

50. Gravekamp C, Paterson Y: Harnessing Listeria monocytogenes to target tumors. Cancer Biol Ther. 2010; 9(4): 257-65.

PubMed Abstract | Publisher Full Text

51. Nguyen VH, Kim HS, Ha JM, et al:: Genetically engineered Salmonella typhimurium as an imageable therapeutic probe for cancer. Cancer Res. 2010; 70(1): 18-23. PubMed Abstract | Publisher Full Text

52. Galmbacher K, Heisig M, Hotz C, et al.: Shigella mediated depletion of macrophages in a murine breast model is associated with tumor regression. PLoS One. 2010; 5(3): e9572.

PubMed Abstract | Publisher Full Text | Free Full Text

53. Quispe-Tintaya W, Chandra D, Jahangir A, et al.: Nontoxic radioactive Listeriaat is a highly effective therapy against metastatic pancreatic cancer. Proc Natl Acad Sci USA. 2013; 110(21): 8668-73.

PubMed Abstract | Publisher Full Text | Free Full Text

54. Coster TS, Hoge CW, VanDeVerg LL, et al.: Vaccination against shigellosis with attenuated Shigella flexneri 2a strain SC602. Infect Immun. 1999; 67(7): 3437-43. PubMed Abstract | Free Full Text

55. Donnelly $\mathrm{O}$, Harrington $\mathrm{K}$, Melcher $\mathrm{A}$, et al.: Live viruses to treat cancer. J R Soc Med. 2013; 106(8): 310-4.

PubMed Abstract | Publisher Full Text

56. Coventry BJ, Lilly CA, Hersey $\mathrm{P}$, et al: Prolonged repeated vaccine immunochemotherapy induces long-term clinical responses and survival for advanced metastatic melanoma. J Immunother Cancer. 2014; 2: 9 . Publisher Full Text

57. Coley WB: Contribution to the knowledge of sarcoma. Ann Surg. 1891; 14(3) 199-220.

PubMed Abstract | Free Full Text

58. Coley WB: Treatment of inoperable malignant tumors with toxins of erysipelas and the bacillus prodigiosus. Trans Am Surg Assn. 1894; 12: 183-212.

59. Coley WB: Disappearance of a recurrent carcinoma after injections of mixed toxins. Ann Surg. 1912; 55: 897-8.

60. Erysipelas and prodigiosus toxins (Coley). JAMA. 1934; 103(14): 1070-71. Publisher Full Text

61. Hoption Cann SA, van Netten JP, van Netten C, et al:: Spontaneous regression: a hidden treasure buried in time. Med Hypotheses. 2002; 58(2): 115-9. PubMed Abstract | Publisher Full Text

62. Hoption Cann SA, van Netten JP, van Netten C: Dr William Coley and tumour regression: a place in history or in the future. Postgrad Med J. 2003; 79(938): $672-680$.

PubMed Abstract | Free Full Text

63. North RJ, Awwad M: T cell suppression as an obstacle to immunologicallymediated tumor regression: elimination of suppression results in regression. Prog Clin Biol Res. 1987; 244: 345-58.

PubMed Abstract

64. Awwad M, North RJ: Immunologically mediated regression of a murine lymphoma after treatment with anti-L3T4 antibody. A consequence of removing L3T4+ suppressor T cells from a host generating predominantly Lyt2+T cell-mediated immunity. J Exp Med. 1988; 168(6): 2193-206. PubMed Abstract | Publisher Full Text | Free Full Text

65. Awwad M, North RJ: Cyclophosphamide (Cy)-facilitated adoptive immunotherapy of a Cy-resistant tumour. Evidence that Cy permits the expression of adoptive T-cell mediated immunity by removing suppressor $T$ cells rather than by reducing tumour burden. Immunology. 1988; 65(1): 87-92. PubMed Abstract | Free Full Text

66. Awwad M, North RJ: Sublethal, whole-body ionizing irradiation can be tumo promotive or tumor destructive depending on the stage of development of underlying antitumor immunity. Cancer Immunol Immunother. 1988; 26(1): 55-60. PubMed Abstract | Publisher Full Text

67. Hill JO, Awwad M, North RJ: Elimination of CD4+ suppressor T cells from susceptible BALB/c mice releases CD8+T lymphocytes to mediate protective immunity against Leishmania. J Exp Med. 1989; 169(5): 1819-27. PubMed Abstract | Publisher Full Text | Free Full Text

68. Awwad M, North RJ: Cyclophosphamide-induced immunologically mediated regression of a cyclophosphamide-resistant murine tumor: a consequence of eliminating precursor L3T4+ suppressor T-cells. Cancer Res. 1989; 49(7): 1649-54.

PubMed Abstract

69. North RJ, Awwad M, Dunn PL: The immune response to tumors. Transplant Proc. 1989; 21 (1 Pt 1): 575-7. PubMed Abstract

70. North RJ, Awwad M: Elimination of cycling CD4+ suppressor T cells with an 
anti-mitotic drug releases non-cycling CD8+ $T$ cells to cause regression of an advanced lymphoma. Immunology. 1990; 71(1): 90-5. PubMed Abstract | Free Full Text

71. Awwad M, North RJ: Radiosensitive barrier to T-cell-mediated adoptive immunotherapy of established tumors. Cancer Res. 1990; 50(8): 2228-33. PubMed Abstract

72. Darrasse-Jèze G, Bergot AS, Durgeau A, et al:: Tumor emergence is sensed by self-specific CD44 ${ }^{\mathrm{hi}}$ memory Tregs that create a dominant tolerogenic environment for tumors in mice. J Clin Invest. 2009; 119(9): 2648-62. PubMed Abstract | Publisher Full Text | Free Full Text

73. Coventry BJ, Ashdown ML, Quinn MA, et al:: CRP identifies homeostatic immun oscillations in cancer patients: a potential treatment targeting tool? J Trans Med. 2009; 7: 102

PubMed Abstract | Publisher Full Text | Free Full Text

74. Ashdown ML Coventry BJ: A Matter of Time. Australasian Science. 2010; 18-20. Reference Source

75. Coventry BJ, Hersey P, Halligan A-M, et al.: Immuno-Chemotherapy Using Repeated Vaccine Treatment Can Produce Successful Clinical Responses in Advanced Metastatic Melanoma. Journal of Cancer Therapy. 2010; 1: 205-213. Publisher Full Text

76. Coventry BJ, Ashdown ML, Markovic SN: Immune Therapies for Cancer Bimodality-The Blind Spot to Clinical Efficacy-Lost in Translation. $J$ Immunother. 2011; 34: 717.

77. Coventry BJ, Ashdown ML: Complete clinical responses to cancer therapy caused by multiple divergent approaches: a repeating theme lost in translation. Cancer Manag Res. 2012; 4: 137-149. PubMed Abstract | Publisher Full Text | Free Full Text

78. Coventry BJ, Ashdown ML: The 20th anniversary of interleukin-2 therapy: bimodal role explaining longstanding random induction of complete clinical responses. Cancer Manag Res. 2012; 4: 215-21.

PubMed Abstract | Publisher Full Text | Free Full Text

79. McNally A, Hill GR, Sparwasser T, et al: $\mathrm{CD}^{+} \mathrm{CD}^{+} 5^{+}$regulatory $\mathrm{T}$ cells control $\mathrm{CD}^{+}$T-cell effector differentiation by modulating IL-2 homeostasis. Proc Natl Acad Sci U S A. 2011; 108(18): 7529-7534.

PubMed Abstract | Publisher Full Text | Free Full Text
80. Boyman $\mathrm{O}$, Sprent $\mathrm{J}$ : The role of interleukin-2 during homeostasis and activation of the immune system. Nat Rev Immunol. 2012; 12(3): 180-190. PubMed Abstract | Publisher Full Text

81. Jain N, Nguyen $\mathrm{H}$, Chambers $\mathrm{C}$, et al:: Dual function of CTLA-4 in regulatory $\mathrm{T}$ cells and conventional $\mathrm{T}$ cells to prevent multiorgan autoimmunity. Proc Natl Acad Sci U S A. 2010; 107(4): 1524-8.

PubMed Abstract | Publisher Full Text | Free Full Text

82. A delicate balance: tweaking IL-2 immunotherapy. Nat Med. 2012; 18(2): 208-209.

PubMed Abstract | Publisher Full Tex

83. Hodi FS, O'Day SJ, McDermott DF, et al.: Improved survival with ipilimumab in patients with metastatic melanoma. N Engl J Med. 2010; 363(8):

711-723.

PubMed Abstract | Publisher Full Text | Free Full Text

84. Prieto PA, Yang JC, Sherry RM, et al:: CTLA-4 blockade with ipilimumab: longterm follow-up of 177 patients with metastatic melanoma. Clin Cancer Res. 2012; 18(7): 2039-2047.

PubMed Abstract | Publisher Full Text | Free Full Text

85. Topalian SL, Hodi FS, Brahmer JR, et al.: Safety, activity, and immune correlates of anti-PD-1 antibody in cancer. N Engl J Med. 2012; 366(26): 2443-54. PublMed Abstract | Publisher Full Text | Free Full Text

86. Brahmer JR, Tykodi SS, Chow LQ, et al:: Safety and activity of anti-PD-L1 antibody in patients with advanced cancer. N Engl J Med. 2012; 366(26): 2455-65.

PubMed Abstract | Publisher Full Text | Free Full Text

87. Ott PA, Hodi FS, Robert C: CTLA-4 and PD-1/PD-L1 Blockade: New Immunotherapeutic Modalities with Durable Clinical Benefit in Melanoma Patients. Clin Cancer Res. 2013; 19(19): 5300-5309.

PubMed Abstract | Publisher Full Text

88. Wolchok JD, Kluger H, Callahan MK, et al:: Nivolumab plus ipilimumab in advanced melanoma. N Engl J Med. 2013; 369(2): 122-33. PubMed Abstract | Publisher Full Tex

89. Murphy KM, Topel RH: The value of health and longevity. J Polit Econ. 2006; 114(51): 871-904. Reference Source 


\section{Open Peer Review}

\section{Current Peer Review Status: ? ?}

\section{Version 1}

Reviewer Report 10 September 2015

https://doi.org/10.5256/f1000research.7216.r10255

(C) 2015 Dalgleish A. This is an open access peer review report distributed under the terms of the Creative Commons Attribution License, which permits unrestricted use, distribution, and reproduction in any medium, provided the original work is properly cited.

\section{Angus Dalgleish}

Department of Oncology, Institute for Infection and Immunity, St George's University of London, London, UK

I was asked to review this article, with full access to previous reviewer's report, Jonathan M Austyn, from the John Radcliffe Hospital. I agree that the article contains some very interesting ideas and concepts, which will be very stimulatory to a wide readership, particularly those studying cancer and practicing cancer (oncologists) who are slowly becoming aware that the immune system is important in the control of cancer and hence the development and evolution.

The review touches on some very broad and very interesting concepts, particularly with regards to evolution over time and the evolutionary difference between innate and adaptive immune systems and he has some of the concepts that are relevant to the hypothesis but perhaps not been elucidated that clearly, especially with regards to the concept of atavism and this has been pointed out by Jonathan Austyn with regards subtle differences in somatic recombination and hypermutation and mutation.

I also agree with rather more reaching, throwaway statements, such as 'cancer occurs in all humans and animals, thus remaining a mystery when several reasons have already been explored, such as random mutations and the concept of escaping tumour surveillance.cancer

Whereas references made to many infectious agents and the fact that they have ended up making up the vast majority of the intron genome, which has been shown to be due to the incorporation of many virus and bacterial sequences. The hypothesis depends very much on the shaping of these agents and the immune system but does not deal adequately with how the immune is shaped by exposure to infectious agents during infant and childhood development.

Much of the references of this article is in large chunks, whereas the authors' papers are listed in large batches, for example; the work by North and colleagues are all listed together and referenced together.

I feel that in addressing this, that they have not acknowledged the work of others who have spent 
a long time working out the affects of basic infectious diseases on the immune system and how this translates to chronic infectious diseases and one author in particular stands out for his work on this and that is Graham Rook, he has published much on this about the exposure of pathogens and the dirt theory, how it impacts on chronic diseases in later life in the western world and, indeed, a review by him and this reviewer (Rook and Dalgleish, 2011) published in Immunological reviews in 2011 goes into great detail with regards to its impact on cancer.

Similarly, the impact of both infectious and non-infectious chronic activation/inflammation, which is relevant to many of the issues raised in this article, have not been addressed sufficiently, especially as it is so relevant to many of the speculations discussed. Again, there are a large number of authors and contributors who have gone from broad brush theories of the association of chronic inflammation and cancer, to those who have gone into great detail pointing out how it impacts on the molecular level of mutations in suppressor genes, such as P53, all the way through to immunological hypoxic pathways, etc., and I do not recognise this from the reference list which, as mentioned, is very block buster in its approach with an author's several contributions all being listed together throughout.

I also feel that, with regards to the homeostatic component focusing purely in Interleukin-2, that although it is true that it is one of several cytokines which contribute to activation and tolerance that a little bit more background should be given.

In conclusion, I think this is a very valuable piece of work of great interest to the rapidly proliferating and emerging population of cancer specialists who are slowly becoming aware that the immune system is extremely important in the management of this disease, a concept that has been ignored for the last few decades and foreign to most oncologist practising today. However, to make it more impactful and a 'must read' article it does require considerable focusing on the aspects raised by the referees and tighter structure, as it does seem to read rather like a speculative lecture in its current format.

With regards to referencing, there is a referral to Klazmann et al. and there is no Klazmann et al. in the references and this is a further example that the references need to be very carefully looked into, although a paper where he is the senior author is listed, I do not think that it is appropriate therefore to refer to it in the text as Klazmann et al.

Competing Interests: I declare that I know Brendon Coventry from Immunotherapy meetings.

\section{I confirm that I have read this submission and believe that I have an appropriate level of expertise to confirm that it is of an acceptable scientific standard, however I have significant reservations, as outlined above.}

Reviewer Report 13 August 2015

https://doi.org/10.5256/f1000research.7216.r9959

(C) 2015 Austyn J. This is an open access peer review report distributed under the terms of the Creative Commons Attribution License, which permits unrestricted use, distribution, and reproduction in any medium, provided the original work is properly cited. 


\section{Jonathan M. Austyn}

Nuffield Department of Surgical Sciences, John Radcliffe Hospital, University of Oxford, Oxford, UK

This article contains some very interesting ideas and concepts. However, to this reviewer (and with the greatest respect to the authors), it tends to read perhaps as 'stream of consciousness' writing rather than a considered scientific article. The authors show abundant enthusiasm in their writing, but this often appears to mask real scientific rigour. It is very difficult to identify a key hypothesis (or hypotheses), the structure of the sections seems to lack definition or focus, and it is sometimes almost impossible to understand what the main conclusions are from each. Furthermore, in a number of places, there seems to be a significant lack of scientific accuracy. For example, regarding some statements regarding the immune system, the authors do not clearly discriminate between somatic recombination (which applies to both T cell receptors and B cell receptors), somatic hypermutation (which applies only to the latter), hypervariable regions (which are present in both) and mutation (per se). As another example, in their discussion of atavism theory, the authors use the term 'tumour immunosuppression' but appear to apply this to the tumour rather than the host, where it really belongs. Even the authors' brief review of the evolution of the immune system seems to lack sufficient focus going from species to species during evolutionary time. There are also some rather vexing 'throwaway statements'. As just one example, regarding cancer, the authors state "The reason why cancer occurs at all in humans and animals thus remains a mystery". While it is certainly true that much remains unknown, the authors might usefully consider further Burnet's concept of tumour surveillance, particularly in its more recent form comprising immunoediting, equilibrium and escape phases. It might also be valuable to reconsider, in relation to the immune system's apparent capacity to eliminate tumours whether or not the immune system actually helps to eliminate the infectious agents (e.g. viruses) that can cause tumorigenesis rather than actual or potentially malignant cells (and, on that point, it is perhaps a little surprising that there is no mention of generic 'DAMPs' and 'PAMPs'). A further criticism is that the choice of immunological mechanisms under discussion sometimes feels rather random - why, for example, do the authors specifically focus on Fc receptors rather than complement receptors, or C-reactive protein rather than the many other molecules that play similar or related roles? Finally, regarding the single diagram that is presented, it is completely unclear why the authors have chosen to illustrate an 'IL-2 [sic] feedback loop'; without any justification this seems to be over-simplistic in the extreme. Nevertheless, to return to the initial point: this article does appear to contain some very interesting material that would potentially be of value to readers of the journal. To do these the greatest justice, however, really does seem to require a very careful, focussed, and considered rewriting of the present text into a completely revised and possibly restructured article.

Competing Interests: No competing interests were disclosed.

I confirm that I have read this submission and believe that I have an appropriate level of expertise to confirm that it is of an acceptable scientific standard, however I have significant reservations, as outlined above. 
The benefits of publishing with F1000Research:

- Your article is published within days, with no editorial bias

- You can publish traditional articles, null/negative results, case reports, data notes and more

- The peer review process is transparent and collaborative

- Your article is indexed in PubMed after passing peer review

- Dedicated customer support at every stage

For pre-submission enquiries, contact research@f1000.com 